\title{
New evidence links changing shelf phytoplankton communities to boundary currents in southeast Tasmania
}

\author{
P. J. Buchanan - K. M. Swadling • R. S. Eriksen • \\ K. Wild-Allen
}

Received: 2 October 2012/ Accepted: 12 June 2013

(C) Springer Science+Business Media Dordrecht 2013

\begin{abstract}
Southern Tasmanian shelf waters are host to the seasonal interplay of Australia's two poleward boundary currents; the East Australian Current (EAC) and the Leeuwin Current (LC). While the behaviour and properties of the LC remain underexplored, strong research focus has allowed insight into how an intensifying EAC has created greater subtropical influence, leading to changes in the physical and biological oceanography of the region. In this cool temperate setting seven species of dinoflagellates, all in the genus Ceratium, which are more typically associated with warm waters of eastern Australia, were observed. This coincided with the seasonal increase in the EAC's southward penetration beginning in October. Despite the seasonal peak in EAC activity, temperature-salinity plots, nutrient, chlorophyll $a$ and phytoplankton concentrations all indicate the presence of subantarctic waters on the shelf and in coastal waters
\end{abstract}

P. J. Buchanan $(\bowtie)$

School of Veterinary and Life Science, Murdoch University, South Street, Murdoch, WA 6150, Australia e-mail: pearse.buchanan@hotmail.com

K. M. Swadling $\cdot$ R. S. Eriksen

Institute of Marine and Antarctic Studies, University of

Tasmania, Private Bag 129, Hobart, TAS 7001, Australia

K. Wild-Allen

CSIRO Hobart Marine and Atmospheric Research Laboratories, Castray Esplanade, GPO Box 1538, Hobart, TAS 7001, Australia in summer. Our results are consistent with the description of the EAC as an erratic, eddy-driven current; this itself allowing the periodic influx of subantarctic waters across the shelf. In winter, temperature-salinity plots and nutrient concentrations indicate that the LC was present in southern shelf waters. In addition to its high nitrate signature, the LC displayed low silicate properties in southern Tasmania. Chlorophyll $a$ concentrations revealed a distinct spring bloom event and an extended, productive summer, typical of temperate and subantarctic systems, respectively. This suggests the region is a transitional state between classic seasonal primary production cycles for temperate and subantarctic waters. This paper links changes in southern Tasmanian microphytoplankton communities to shelf ventilation by the EAC, the LC and subantarctic waters, and provides new insight into the oceanography of the region. Consequently, this study provides an awareness of potential phytoplankton perturbations that may be applied to other coastal cool temperate marine environments.

Keywords Phytoplankton · Ocean warming · Ceratium - Leeuwin Current - East Australian Current . Range extension · Primary production regimes

\section{Introduction}

Global climate models indicate that observed trends of oceanic warming in southeast Australia are the 
greatest in the Southern Hemisphere and that this warming will continue well into this century (Ridgway and Hill 2009). Many lines of evidence point to the intensification of the East Australian Current (EAC) as the main cause of warming (Hill et al. 2008; Thompson et al. 2008; Ridgway and Hill 2009; Johnson et al. 2011). The EAC is a highly energetic and variable boundary current that is dominated by mesoscale eddies south of its separation from the east Australian mainland at approximately $32.5^{\circ} \mathrm{S}$ (Ridgway and Hill 2009). Its southern advancement is due to a spin-up of the South Pacific subtropical gyre (Ridgway and Hill 2009). A 58-year long record (1944-2002) from the Maria Island National Reference Station (MINRS), a long term oceanographic monitoring station run by the Integrated Marine Observing System (IMOS) on the east coast of Tasmania, highlights increased southward penetration of the EAC into east Tasmanian coastal waters (Ridgway and Hill 2009). The MINRS data highlights that the extension of the EAC is responsible for significant changes to the coastal environment of eastern Tasmania. This includes an increase of sea surface temperature (SST) at $2.28{ }^{\circ} \mathrm{C}$ per century, increasing salinity of 0.34 per century (Ridgway and Hill 2009) and a long-term reduction in silicate (Thompson et al. 2009), all characteristics typical of subtropical water (Ridgway 2007).

Southern Tasmanian shelf waters are host to a number of economically important fisheries that may be impacted by greater subtropical influence. Most notable are the Southern Rock Lobster and Abalone fisheries. Blacklip Abalone (Haliotis rubra) and Southern Rock Lobster (Jasus edwardsii) represent Tasmania's two most valuable fisheries (Punt and Kennedy 1997; Tarbath and Gardner 2011). Tasmania supplies approximately $30 \%$ of the global market for wild caught Abalone each year (ABARE 2010) and approximately a quarter of this catch is consistently harvested from southern Tasmanian reefs, most of which is sourced from the Actaeon Islands (Tarbath and Gardner 2011). It is predicted that increasing temperature, resulting from a long-term intensification of the EAC, will significantly reduce the size of abalone at maturity (Johnson et al. 2011). Hence longterm warming in Tasmanian near shore reefs, as demonstrated by the MINRS, has the potential to cause a steady reduction in Abalone yields. In contrast, present warming of southern Tasmanian waters has caused almost a doubling in the growth rates of
Southern Rock Lobsters (Pecl et al. 2009). Additionally, it is predicted that the settlement of puerulus larvae onto southern Tasmanian reefs will increase as the subtropical convergence moves further south, while puerulus recruitment in northeast and east Tasmania is expected to decline (Pecl et al. 2009). Thus, both fisheries within the southern Tasmanian region are likely to be impacted significantly by the changing oceanic conditions, albeit in opposing ways.

The increasing influx of subtropical water into the region has had real impacts on biological communities. The boundary currents of Australia, the Leeuwin Current (LC) and EAC, are the primary drivers of onshelf biological oceanography (Thompson et al. 2009). Changes to coastal communities are therefore reflective of changes in the physics of these currents. A number of biological impacts attributed to the southerly extension of the EAC have so far been documented in east and southeast Tasmanian waters. These include the expansion of the barren-forming urchin Centrostephanus rodgersii from the Australian mainland (Ling et al. 2009), dramatic declines in macroalgal species, most notably the giant kelp Macrocystis pyrifera (Johnson et al. 2011), the restriction in the diatom spring bloom at Maria Island (Thompson et al. 2009), the presence of the heterotrophic dinoflagellate Noctiluca scintillans (McLeod et al. 2012), and an increased proportion of warm-water species of zooplankton (Johnson et al. 2011). Tasmanian coastal waters are consequently experiencing significant biological shifts.

Planktonic communities, which are sensitive to regional oceanography due to their free-floating nature (Hays et al. 2005) and physiological coupling to temperature (Richardson 2008), can be expected to change. Changes to phytoplankton community dynamics can dramatically alter an ecosystem by introducing mismatches between successive trophic levels (Edwards and Richardson 2004) and by instigating a reorganisation of the community (Hays et al. 2005). Temperate environments are particularly vulnerable to seasonal physical abnormalities due to the dependency of higher trophic levels on the timing of phytoplankton pulses and associated peaks in primary production (Edwards and Richardson 2004). Many species of higher trophic levels rely on these production peaks as signals for annual reproduction (Doney et al. 2012), while others depend on specific prey preferences that become mismatched as plankton communities change 
(Brander 2010). As a consequence, long-term changes in the phytoplankton of southern Tasmania could have considerable repercussions for local fisheries as phenology and community compositions adjust.

Adequate physical and biological oceanographic exploration in a changing Tasmanian ocean climate is necessary for effective fisheries management. This paper provides evidence for the following in the context of the Southern Tasmanian inshore environment: (a) changes to the microphytoplankton community that are occurring as a result of the EAC's continued poleward extension and potential consequences of this, (b) a new perspective on both the behaviour and physical properties of major boundary currents (EAC and LC) in the region, and (c) how the dynamic interaction of subtropical and subantarctic waters influence the seasonal cycles of primary production in southern Tasmania.

\section{Materials and methods}

Study site dynamics

The complex mesoscale dynamics in southern Tasmania are driven by the seasonally alternating influence of Australia's two major boundary currents (Fig. 1). In summer the EAC is dominant, while in winter the LC dominates the region. Spring and autumn experience transitional stages, whereby neither current clearly dominates (Cresswell 2000).

The physical signature of the EAC has been studied thoroughly and is known to be warm $\left(>18^{\circ} \mathrm{C}\right)$, highly saline ( $>35.6$ ) and poor in nutrients, especially silicate (Harris et al. 1987; Ridgway 2007). Ridgway (2007) described the penetration of the EAC into east Tasmanian waters after examining data collected at the MINRS, and proposed that the current spills onto the shelf in January and peaks in influence during February and March. However, evidence for the spread onto the continental shelf in southern Tasmania is limited in the data presented, and the warm-water tongue appeared to be constrained to the shelf break south from Tasman Island (shown on Fig. 1). This observation was supported by an earlier study conducted by Harris et al. (1987), whereby physical evidence of the EAC was absent from temperature to salinity (TS) plots in shelf waters south of Tasman Island.
During winter the LC, which extends from Western Australia (WA) across the Great Australian Bight and down the west coast of Tasmania (where it is also known as the Zeehan Current), is dominant in southern Tasmanian waters and the EAC is retracted north (Cresswell 2000). The LC transports relatively warm and saline waters to Tasmania as it flows down the west coast, around the southern tip and heads northeast up the east coast (Ridgway 2007). Unlike the EAC, the LC's flow is remarkably consistent and the current remains almost entirely constrained to the continental shelf (Ridgway 2007). Consequently, modified subtropical waters originating in WA are reliably delivered to southern Tasmanian shelf waters in the winter, providing warm and saline conditions relative to those offshore. Despite its potential influence on coastal waters, little information exists regarding the physical signature of the LC in Tasmania. Ridgway (2007) attributed water of a subtropical nature at Maria Island during winter to the LC, and described it as approximately $12{ }^{\circ} \mathrm{C}, 34.8-35.2 \mathrm{psu}$, and rich in nitrates $(\sim 4 \mu \mathrm{M})$.

\section{Field sampling}

Sampling was conducted at three sites (Fig. 1) in quasi-monthly trips from June 2011, to March 2012. All sites were sampled on most occasions, although due to poor weather it was not possible to sample offshore sites in June and August.

Water samples were collected using an 8 L Niskin bottle at the subsurface $(0.5 \mathrm{~m}), 10 \mathrm{~m}$ and within $5 \mathrm{~m}$ of the bottom at each site (40 $\mathrm{m}$ at Site 1; $70 \mathrm{~m}$ at Site 2; $90 \mathrm{~m}$ at Site 3). Water samples were also collected at $50 \mathrm{~m}$ at Site 3. Subsamples were taken to determine concentrations of macronutrients, chlorophyll $a$ (for primary production) and phytoplankton at each depth. Samples for phytoplankton analysis were preserved with Lugols iodine fixative solution (Hötzel and Croome 1998). Nutrient samples (unfiltered) were stored in the dark at $-20{ }^{\circ} \mathrm{C}$ following collection. Both phytoplankton and chlorophyll $a$ samples were kept under cool, dark conditions until filtered on return to the Institute for Marine and Antarctic Studies laboratories.

Water profiles measuring salinity, temperature and dissolved oxygen were taken at each site using a Seabird SBE 19 plus CTD (full water column profile) and/or a YSI 6600 V2 Sonde CTD (profile limited to $35 \mathrm{~m})$. 

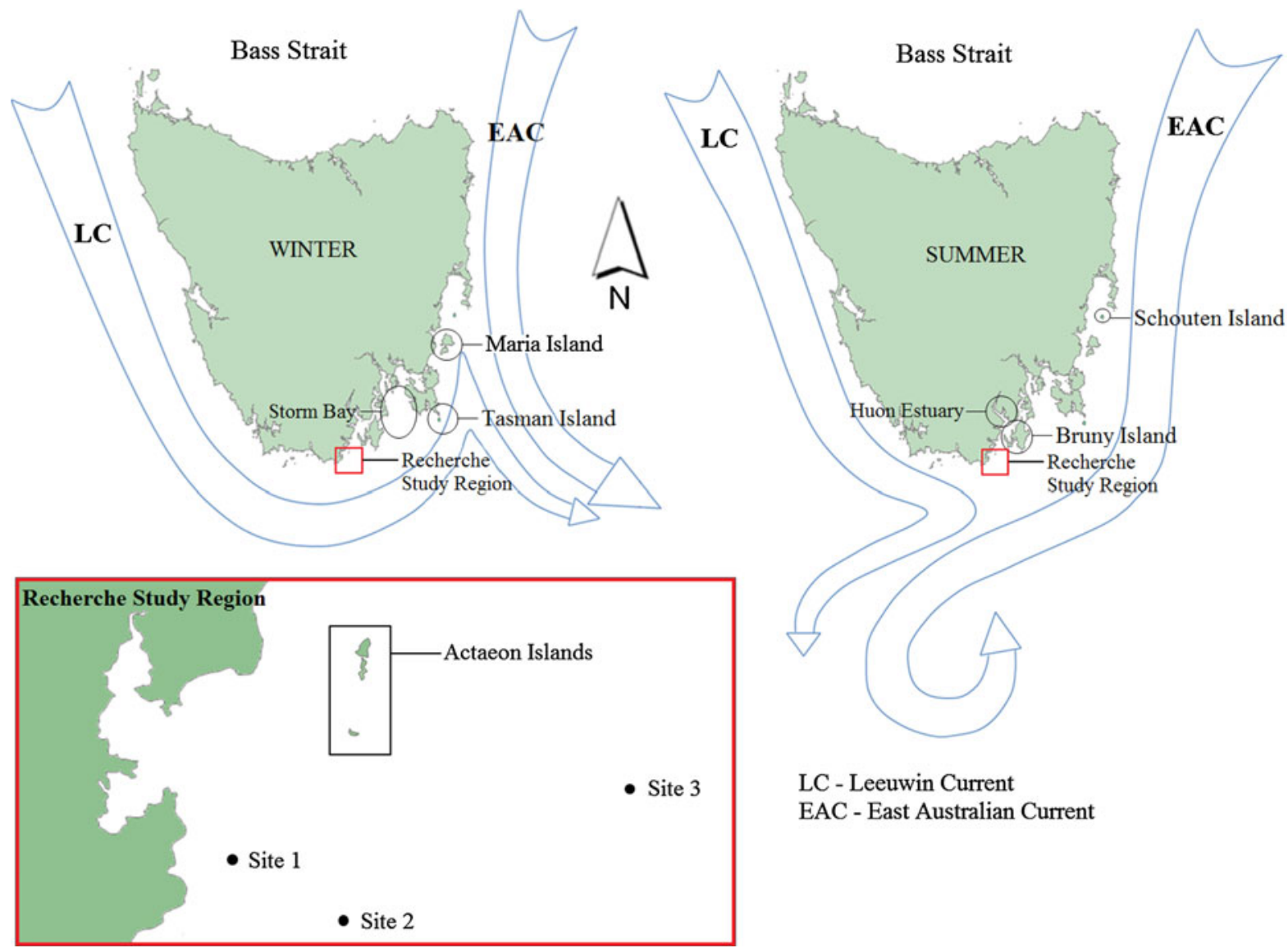

LC - Leeuwin Current

EAC - East Australian Current

Fig. 1 The region in which sampling took place and other locations of importance, with respect to the winter and summer interaction between the Leeuwin (Zeehan) and East Australia Currents in Tasmania (Cresswell 2000)

\section{Laboratory analysis}

To determine chlorophyll $a$ concentrations, $2 \mathrm{~L}$ of seawater were filtered through a $47 \mathrm{~mm}$ glass fibre filter (Whatman $\mathrm{GF} / \mathrm{F}$ ) under low light conditions and frozen at $-20{ }^{\circ} \mathrm{C}$. Photosynthetic pigments were extracted into 90:10, acetone:water, (vol:vol). Samples were sonicated and then kept in the dark at $4{ }^{\circ} \mathrm{C}$ for approximately $15 \mathrm{~h}$. Samples were then centrifuged for two $15 \mathrm{~min}$ cycles at $9,000 \mathrm{rpm}$ to separate filter paper from solution. Absorbances were measured using a Varian CBE Cintra 10e Spectrometer. Standard equations were applied to determine the amount of chlorophyll present in the samples (Parsons et al. 1984).

Preserved samples for phytoplankton were transferred to $1 \mathrm{~L}$ glass measuring cylinders; volumes were recorded and phytoplankton cells concentrated by settling. Samples were sequentially settled and sample volume carefully reduced to 200 , then 50 and finally
$15 \mathrm{~mL}$. At least 1 week settling time occurred between sequential transfers. Concentrated samples were thoroughly mixed before a $1 \mathrm{~mL}$ aliquot was taken, placed in a Sedgwick Rafter counting chamber and examined under a Leica DMLB compound microscope using phase contrast. Settling and counting methodologies were based on the methods described in Hötzel and Croome (1998).

For larger phytoplankton $(>20 \mu \mathrm{m}), 100 \%$ of the counting chamber was scanned. For nanoplankton, (cells $2-20 \mu \mathrm{m}$ ) the chamber was examined at $200 \times$ and $400 \times$ until at least $20 \%$ of the chamber had been counted. Cells were identified to the lowest taxonomic level possible and grouped into diatoms, dinoflagellates and flagellates.

Dissolved nitrate + nitrite, phosphate and silicate concentrations $(\mu \mathrm{M})$ were determined using standard colorimetric methodology (Grasshoff et al. 1983) as adapted for flow injection analysis on a 5 channel 
LACHAT Quik-Chem 8000 autoanalyser by the Hydrochemistry unit at CSIRO Marine and Atmospheric Research Laboratories.

\section{Data analysis}

Practical salinity and temperature were converted to absolute salinity and conservative temperature, respectively, using the Gibbs Sea Water (GSW) Oceanographic Toolbox (version 3) (Feistel 2008) within MatLab R2011b. TS plots were produced using the bottom-up data from the profile cast, as significantly more scatter was observed in the data from top to down casts. Depth profiles of nutrients and chlorophyll $a$ data were produced using SIGMA-Plot (version 11).

\section{Remote sensing}

High resolution regional SST imagery were collated to provide insight into mesoscale changes around Tasmania (IMOS 2012). Images prior to December 2011 represent NOAA satellite pass-overs, while those from December 2011 onwards are included in the L3U SST data produced by the Bureau of Meteorology for the IMOS Satellite Remote Sensing Facility. Data were sourced from the Integrated Marine Observing System (IMOS). Selected images represent daily conditions to provide a portrayal of mesoscale dynamics during winter, spring and summer (Fig. 2).

\section{Connectivity model}

The CSIRO online tool CONNIE2 (CONNIE 2012) was used to estimate likely source areas for nutrient supply to southern Tasmania. CONNIE2 uses ocean currents generated from the data assimilating threedimensional hydrodynamic model OFAM (Ocean Forecasting Australia Model) CSIRO reanalysis product (BRAN) to track passive tracers at specified locations and depths (Condie 2005; Condie et al. 2012). The online tool was used to illustrate possible source locations for nutrients arriving in coastal waters in winter (Jun-Aug), spring (Sept-Nov) and summer (Dec-Feb); statistics were averaged over 7 years (2001-2007) to illustrate the probable origins of seasonal flow into the region (Fig. 3).

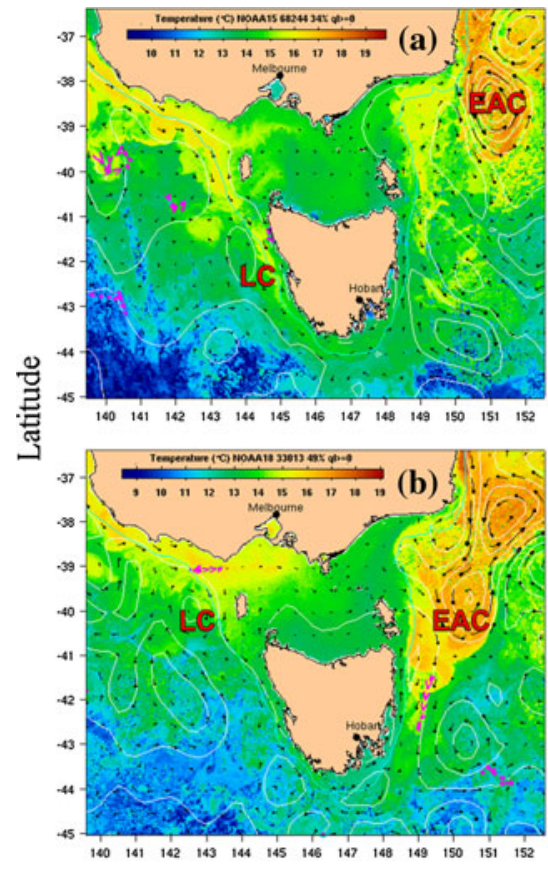

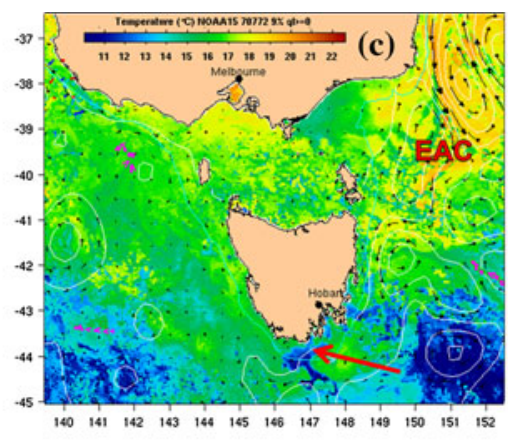

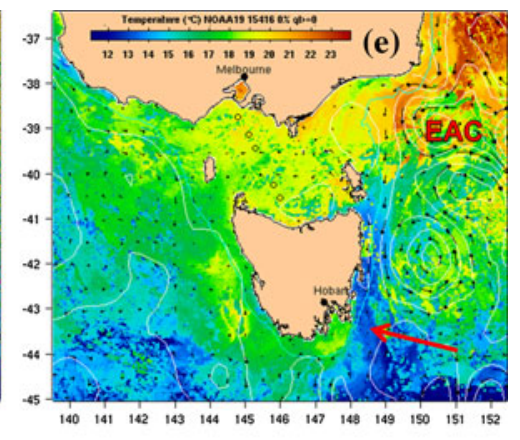

Longitude

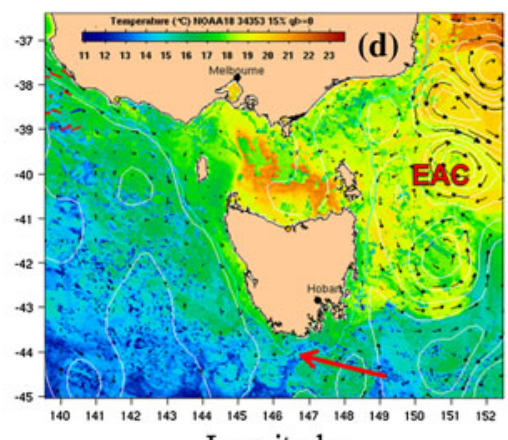

Current. Red arrows point to areas of pronounced incursions of modified subantarctic water into Tasmanian shelf environments. a 29/06/2011, b 17/10/2011, c 23/12/2011, d 20/01/2012 and e $04 / 02 / 2012$

Fig. 2 Surface Sea Temperature plots (IMOS 2012) displaying winter (a), spring (b) and the events of 2011/2012 summer interplay between subtropical (EAC water) and subantarctic waters (c-e). LC Leeuwin Current, EAC East Australian 


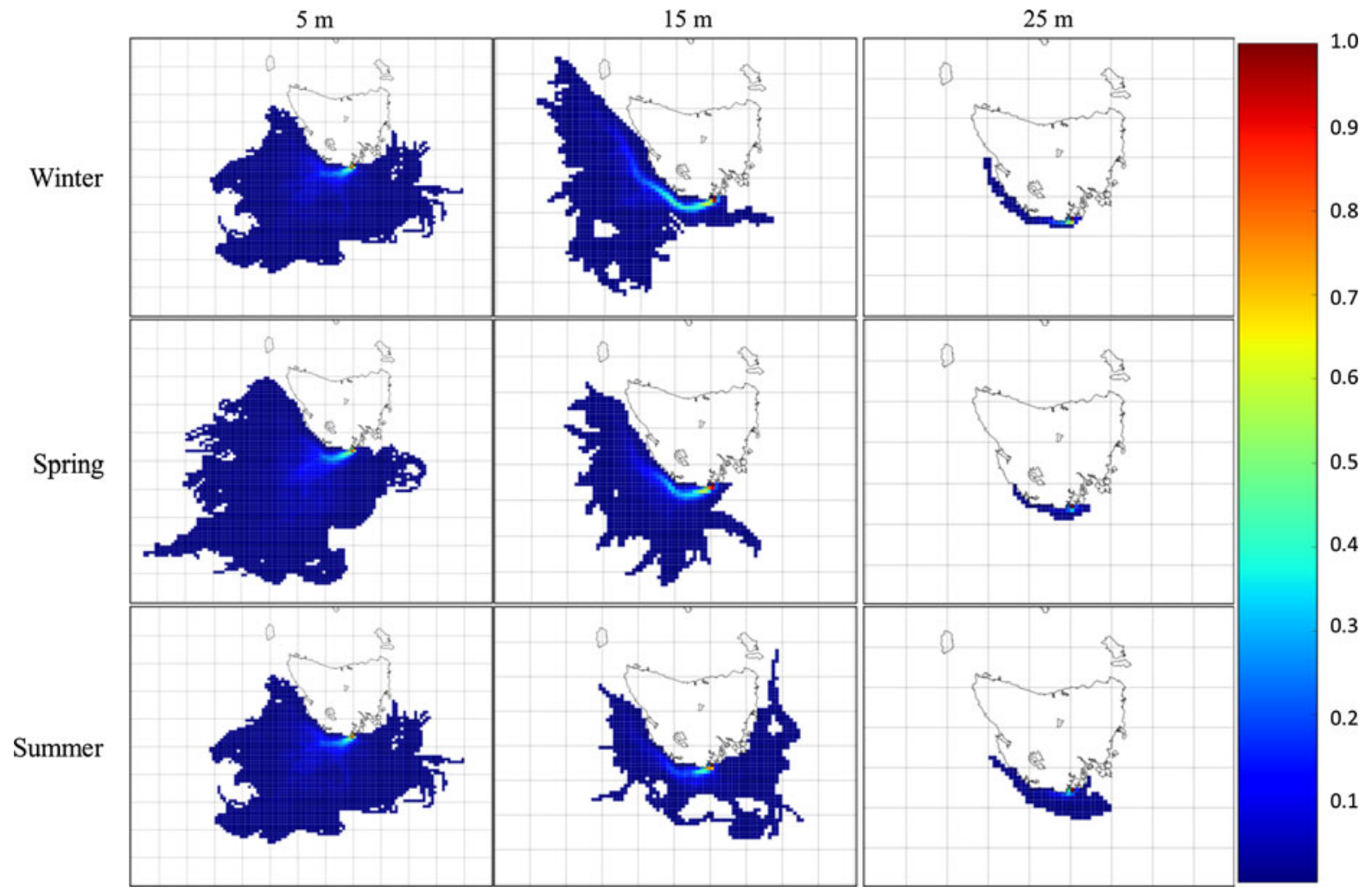

Fig. 3 Connie 2 (CONNIE 2012) model results displaying the likely origins of water over a 30 day dispersal period flowing into a sink representing the study site in southern Tasmania. Dispersal of water at 5, 15 and 25 metre depths were applied to

\section{Results}

Phytoplankton

Two distinct microphytoplankton communities were observed (Fig. 4). During June, July, August and the September spring bloom there were greater numbers of diatoms, with the diatom:dinoflagellate ratio greatest at site 3 in September. A shift in the community was observed in October when dinoflagellates became more abundant, and the dinoflagellate community became increasingly diverse. A number of warmwater species from the genus Ceratium were present in samples from October. These species included Ceratium candelabrum, Ceratium macroceros, Ceratium concillans, Ceratium falcatiforme, Ceratium paradoxides, Ceratium symmetricum, and Ceratium $c f$. vulture (shown, respectively, in Fig. 5a-e). The large, heterotrophic, warm-temperate dinoflagellate $N$. scintillans was also identified in summer (Fig. 5h). These winter (01/06-31/08), spring (01/09-30/11) and summer (01/ 12-28/02) oceanographic conditions averaged over a 7 year period (2001-2007). Colourbar represents the proportional likelihood of water from a region flowing into the study site

warm-water species were accompanied by the rare subantarctic dinoflagellate Dinophysis truncata (Fig. 5i), which was identified during December at the inshore site. Despite fluctuations in the abundance and diversity of the diatom and dinoflagellate communities, small flagellates $(2-15 \mu \mathrm{m})$ consistently dominated phytoplankton abundances throughout the entire sampling period (Fig. 4). Also, a number of common phytoplankton species and groups from the Tasmanian region were identified. The diatoms Rhizosolenia fallax and Nitzschia cf. longissima, and the dinoflagellate Scripsiella trochoidea were present in all samples. Winter samples contained a large number and high diversity of benthic diatoms, which were present from surface to bottom waters. The spring increase in phytoplankton included a notable increase in Lauderia sp., which composed the bulk of diatom abundance during the spring bloom. Coscinodiscus wailesii was absent from surface waters after September 2011 and was found in deep samples in October. 
Fig. 4 Change in the abundances (cells $\times 10^{4} \mathrm{~L}^{-1}$ ) of diatoms, photosynthetic dinoflagellates and small flagellates $(2-20 \mu \mathrm{m})$ across the sampling period for all three sites
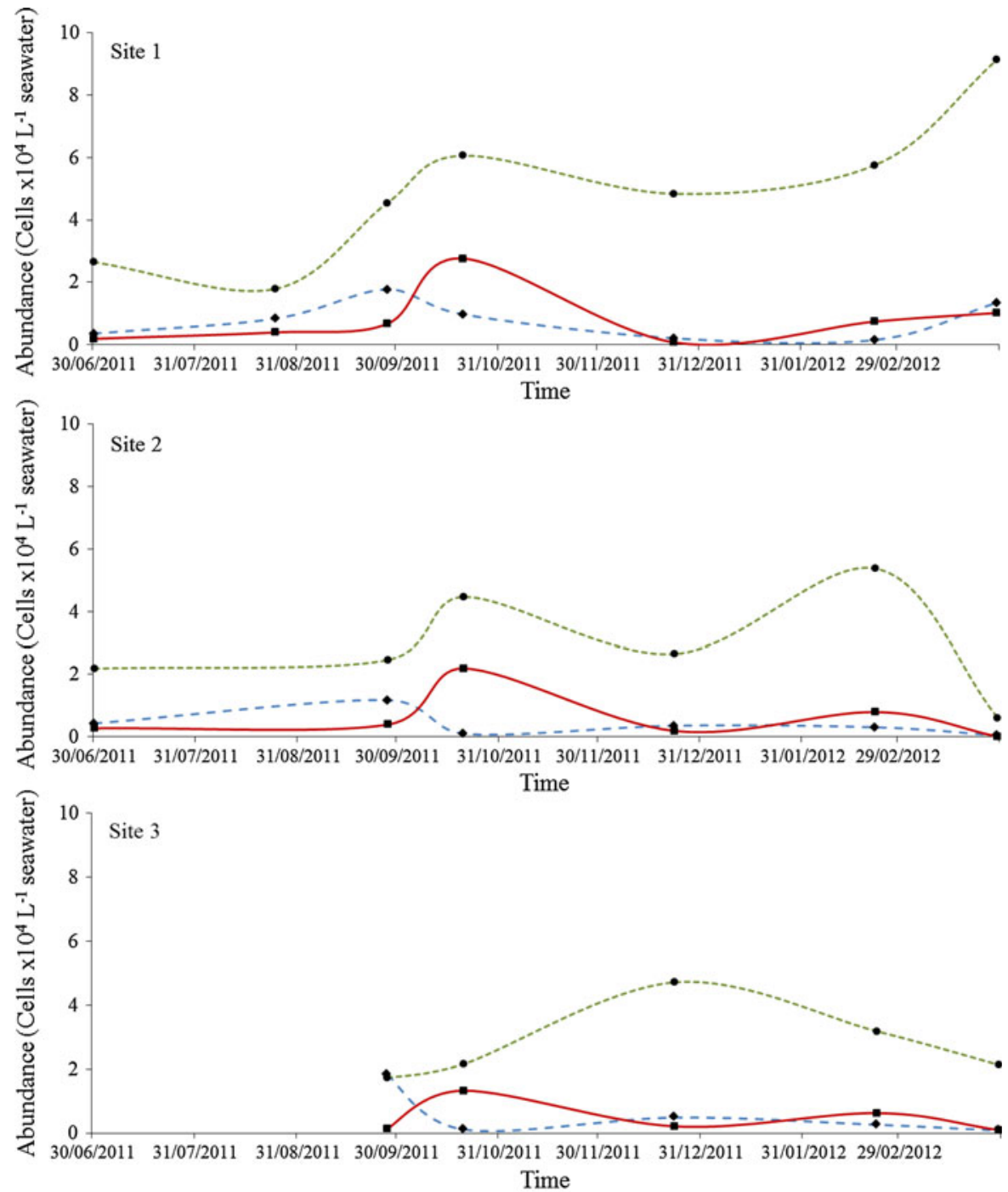

- - Diatoms $\rightarrow-$ Dinoflagellates $\quad-\bullet--$ Flagellates

Following the spring bloom, heterotrophic Protoperidinium and Gyrodinium species showed a strong increase in abundance and species diversity, coinciding with the shift to a dinoflagellate dominated community. A decrease in the abundance and diversity of both diatoms and dinoflagellates occurred in February and March. However, an increase in the warm temperate dinoflagellate Oxytoxum was noted in February.

Chlorophyll $a$ concentrations (Fig. 6a) revealed a mixed water column in winter, followed by a spring surface bloom in September; the effects of water column stratification were observed during summer, while there was a reduction in production towards autumn. Sites 1 and 2 revealed peak chlorophyll $a$ standing stock in surface waters $(0.5 \mathrm{~m})$ in September, where concentrations of 0.98 and $0.86 \mathrm{mg} \mathrm{m}^{-3}$, respectively, were measured. Site 3 exhibited peak production in surface waters $(0.5 \mathrm{~m})$ in December and March, when chlorophyll $a$ concentrations were measured at 0.70 and $0.81 \mathrm{mg} \mathrm{m}^{-3}$, respectively. During summer peak production typically occurred at $10 \mathrm{~m}$, with concentrations in December (1.01-1.34 $\left.\mathrm{mg} \mathrm{m}^{-3}\right)$, February (0.63-1.20 $\mathrm{mg} \mathrm{m}^{-3}$ ) and March $\left(0.54-1.03 \mathrm{mg} \mathrm{m}^{-3}\right)$ consistently greater than spring values. A spike in chlorophyll $a$ occurred in October bottom samples. 

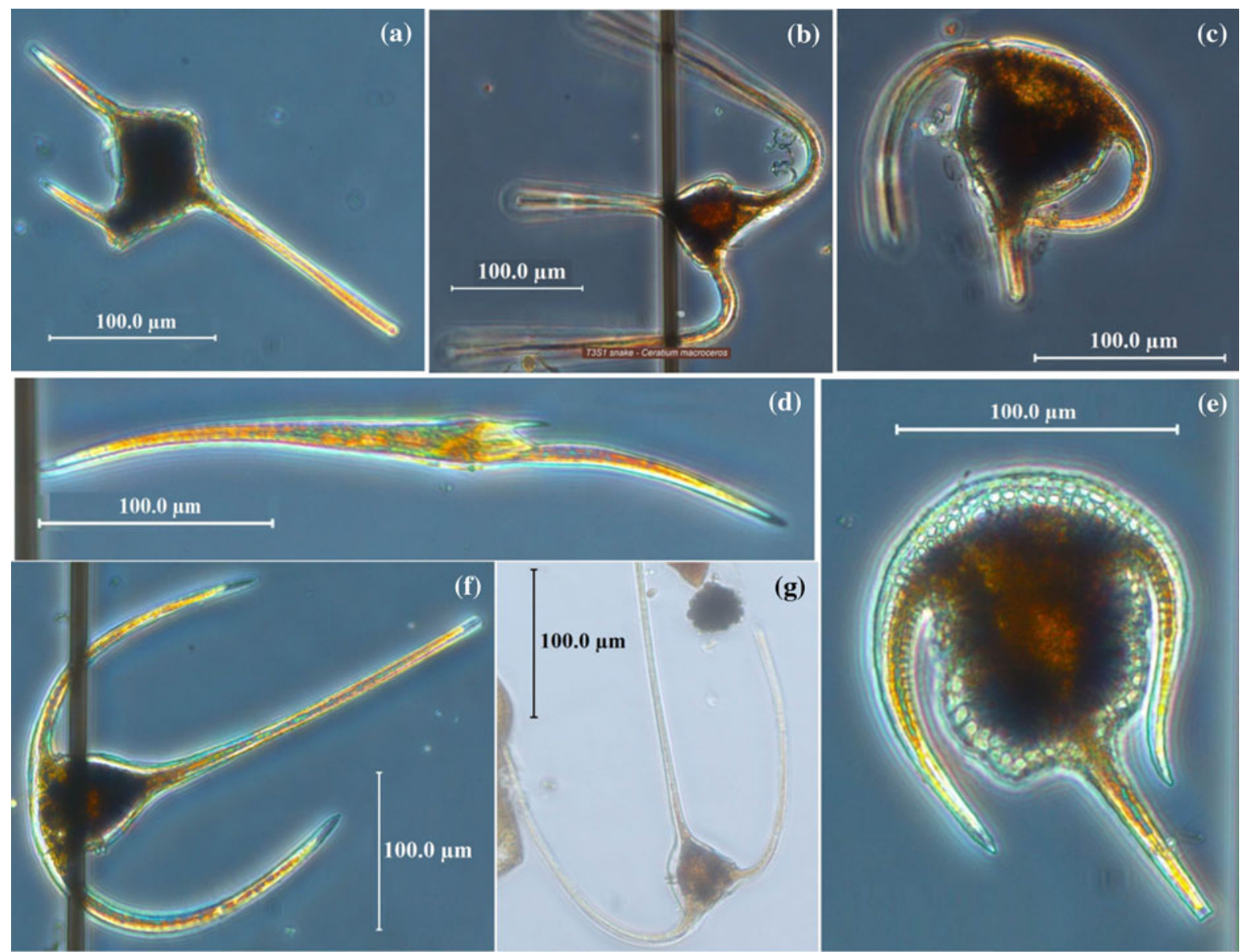

(d)
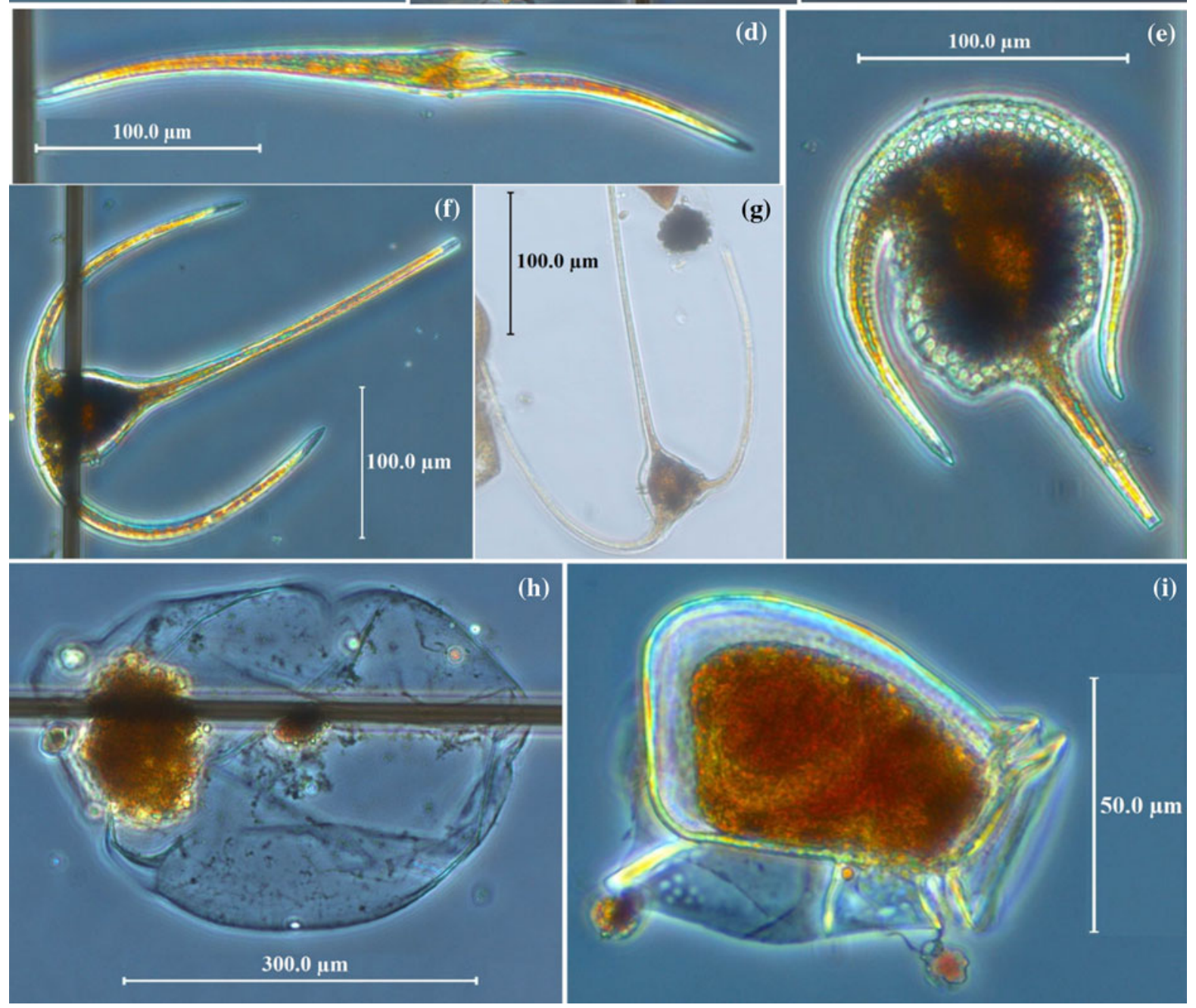

Fig. 5 Warm-water dinoflagellates coinciding with the subantarctic dinoflagellate D. truncata: a C. candelabrum, b $C$. macroceros, c C. concilians, $\mathbf{d}$ C. falcatiforme, e $C$. paradoxides, $\mathbf{f} C$. symmetrium, $\mathbf{g}$ C. c $f$. vultur, $\mathbf{h}, N$. scintillans and i $D$. truncata

\section{Environment}

Nutrient concentrations in surface and bottom waters did not differ significantly in winter. Nitrate + nitrite
(Fig. 6b) and phosphate (Fig. 6c) surface concentrations were highest during winter, with 3.17-3.42 $\mu \mathrm{M}$ and $0.32-0.37 \mu \mathrm{M}$ respectively, and showed a gradual decline into September (1.42-2.60 $\mu \mathrm{M}$ and 

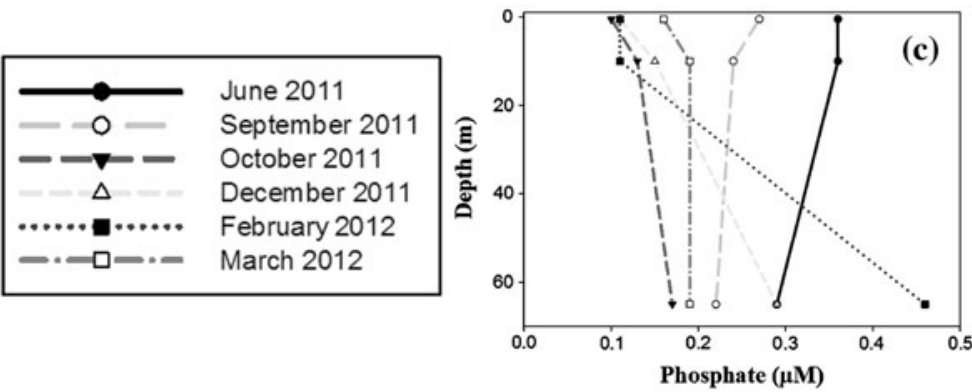

(a)
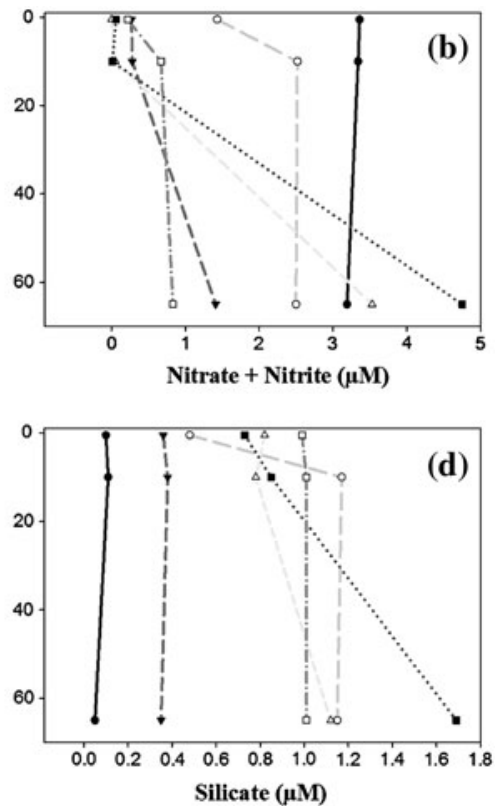

Fig. 6 Depth $(\mathrm{m})$ profiles of chlorophyll $\alpha\left(\mathrm{mg} / \mathrm{m}^{3}\right)$, silicate $(\mu \mathrm{M})$, nitrate + nitrite $(\mu \mathrm{M})$ and phosphate $(\mu \mathrm{M})$ for each month sampled at site 2 . Sites 1 and 3 (omitted) show similar patterns

$0.27-0.31 \mu \mathrm{M}$, respectively). Silicate (Fig. 6d) surface concentrations were lowest in winter $(0.10-0.17 \mu \mathrm{M})$, highest in September $(0.48-1.14 \mu \mathrm{M})$ and then exhibited a decline to near winter levels in October $(0.36-$ $0.40 \mu \mathrm{M})$. Surface concentrations of nitrate + nitrite and phosphate also exhibited depletion in October (0.27-0.29 and 0.10-0.13 $\mu \mathrm{M}$, respectively). December and February nutrient profiles demonstrated surface depletion. The highest nutrient concentrations recorded for all months were in February at site 3 at 90 m, where nitrate + nitrite $=5.55 \mu \mathrm{M}$, phosphate $=0.5 \mu \mathrm{M}$ and silicate $=1.88 \mu \mathrm{M}$, with notable increases also recorded at depth at sites 1 and 2 in February. Nitrate + nitrite and phosphate surface concentrations remained lower in summer and March (0.00-0.64 and $0.10-0.18 \mu \mathrm{M}$, respectively) compared to winter concentrations. Silicate increased throughout the water column during summer, with surface concentrations between 0.66 and $1.00 \mu \mathrm{M}$ and bottom concentrations between 0.64 and $1.88 \mu \mathrm{M}$, following the decline in October. There was nutrient repletion of surface waters in March, where nitrate + nitrite $=0.22-0.64 \mu \mathrm{M}$, phosphate $=0.15-0.18 \mu \mathrm{M}$ and silicate $=0.98-1.00$ $\mu \mathrm{M}$, and a decline in bottom waters, where nitrate + nitrite $=0.83-0.89 \mu \mathrm{M}, \quad$ phosphate $=0.19-0.20 \mu \mathrm{M}$ and silicate $=0.101-1.03 \mu \mathrm{M}$.
In general, TS plots (Fig. 7) illustrated a seasonal progression from mixed (June to September) to stratified water column structure (October-February), with a return to mixing in March. Water temperatures of $12-13{ }^{\circ} \mathrm{C}$ persisted throughout winter to September. The water column was completely mixed in June and August, with temperature and salinity falling within the definition of the LC's physical signature by Ridgway (2007) as approximately $12{ }^{\circ} \mathrm{C}$ and $34.8-$ 35.2 psu. A slight decrease in salinity $\left(0.08 \mathrm{~g} \mathrm{~kg}^{-1}\right)$ was evident in September at site 1, and there was no evidence of warming. As stratification was not evident at the inshore site in September, the decline in salinity was observed throughout the water column. The first strong instances of stratification occurred in October, accompanied by a slight increase in both inshore and offshore surface temperatures $\left(>13{ }^{\circ} \mathrm{C}\right)$. By December stratification was well established. A sharp increase in surface temperature $\left(>15^{\circ} \mathrm{C}\right)$ and a slight increase in temperature of waters below the thermocline $\left(\sim 13.5^{\circ} \mathrm{C}\right.$ ) was observed at all sites. The warming was accompanied by an increase in salinity. During February there was slight warming and significant declines in salinity $\left(\sim 0.2 \mathrm{~g} \mathrm{~kg}^{-1}\right)$ to winter levels at sites 1 and 2. Greater mixing was evident at all sites in March, with a shoaling of the thermocline and salinity 

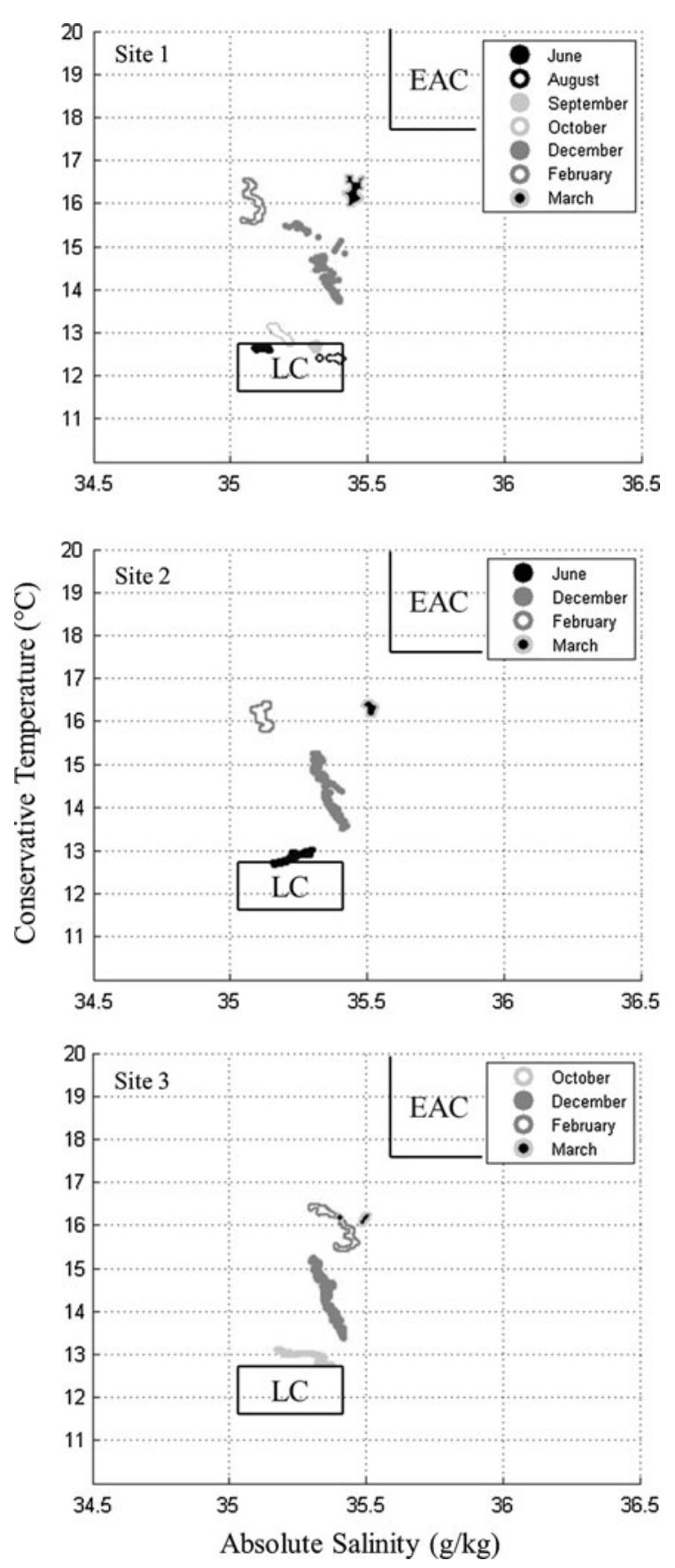

Fig. 7 Combined temperature-salinity plots for each sampling site showing physical water property changes between months. Temperature and salinity have been converted to conservative temperature $\left({ }^{\circ} \mathrm{C}\right)$ and absolute salinity $\left(\mathrm{g} \mathrm{kg}^{-1}\right.$ seawater) using Gibbs seawater oceanographic toolkit increasing to the maximum observed during the sampling period $\left(>35.5 \mathrm{~g} \mathrm{~kg}^{-1}\right)$.

\section{Discussion}

Since monitoring began in 1944, the MINRS has presented a clear trend of increasing ocean temperature of $2.28{ }^{\circ} \mathrm{C}$ per century on the east coast of Tasmania (Ridgway and Hill 2009). Our observation of warm-water Ceratium species in southern Tasmanian coastal waters $\left(\sim 43^{\circ} 6^{\prime} \mathrm{S}, \sim 146^{\circ} 6^{\prime} \mathrm{E}\right)$ indicates that this region may also be experiencing warming. Seven Ceratium species, which to our knowledge have not been previously found this far south in Australian waters, were observed during October and December, months in which dinoflagellates outnumbered diatoms. The sighting of C. candelabrum, C. macroceros, C. concillans, C. falcatiforme, C. paradoxides, $C$. symmetricum, and $C$. cf. vultur represent significant range expansions. C. paradoxides, $C$. vultur and $C$. falcatiforme were previously observed outside their known range in Bass Strait by Huisman (1989) in the 1980s and their identification in southern Tasmania represents a continued extension of their range. Prior sampling targeting phytoplankton, however, is limited for southern Tasmania and it cannot be said with certainty that the presence of these species has not occurred previously. Sampling in Storm Bay (Harris et al. 1991), the Huon Estuary (Thompson et al. 2008) and at various sites in the southwest Tasman Sea (Harris et al. 1987) represent, geographically, the closest research incorporating phytoplankton species analysis conducted with respect to our sites. These projects make no mention of observing the aforementioned Ceratium species. Thompson et al. (2008), however, describes a rise in local dominance of dinoflagellates in the Huon Estuary from 1996 to 2005, and suggests the greater influx of EAC water into east Tasmania as a likely contributing factor. The Ceratium species are known from warm waters of the Tasman Sea (Hallegraeff et al. 2010) and, considering the season, we suggest that the strengthening EAC was responsible for their appearance in southern Tasmania. 
The poleward extension of tropical and warmtemperate Ceratium species has been well documented in the Northern Hemisphere (Dodge and Marshall 1994; Johns et al. 2003; Barnard et al. 2004; Hays et al. 2005; Edwards et al. 2006), and it is predicted that subsequent expansions will occur into the future (Turin-Ley et al. 2009). As Tasmania is expected to experience continued ocean warming into this century (Ridgway and Hill 2009), it follows that introductions of Ceratium, and perhaps other warm water species, will also be observed. The creation of mixed communities and transitional zones are common impacts of changing oceanographic conditions. Research focussing on the biological implications stemming from the presence of warm-water species in cooler regions highlights possible declines in coolwater species (Scavia et al. 2002; Beaugrand 2004; Turin-Ley et al. 2009; Johnson et al. 2011), declines in overall plankton diversity (Johns et al. 2003; TurinLey et al. 2009) and the potential reorganisation of plankton phenology, community structure and abundance (Hays et al. 2005; Turin-Ley et al. 2009). Regarding Tasmania specifically, Johnson et al. (2011) suggests that population-level changes to commercially important invertebrates, such as abalone and rock lobster stocks, are of concern as Tasmanian plankton communities are modified. However, specific examples of the impacts to fisheries that stem from recorded expansions of Ceratium species are in their infancy. One notable example from Johns et al. (2003) concluded that the apparent displacement of diatoms due to the significant increase in $C$. arcticum in the North Sea, first noted in the 1990s, played a key role in the collapse of the Atlantic Cod fishery in the Grand Banks region of east Canada. This hypothesis is well supported (e.g., Beaugrand et al. 2003; Beaugrand 2004; Hays et al. 2005). Similarly, declines in catch in the Western Horse Mackerel fishery in the North Sea were attributed to the plankton regime shift that occurred in the late 1980s (Reid et al. 2001). This regime shift involved an increase in the abundance of Ceratium species (Dickson et al. 1992). Reid et al. (2001) argued that bottom-up step-wise changes eventuated in declining catches in southern, central and eastern areas of the North Sea. Roughly a decade prior, the North Sea ecosystem exhibited similarly dramatic changes in phytoplankton composition attributed to warming SST and altered regional oceanographic dynamics, with precipitous declines in some Ceratium species in the late 1970s (Edwards et al. 2002). C. macroceros, a once abundant part of the phytoplankton community, became completely absent from surveys following 1979 (Weijerman et al. 2005). Almost simultaneously, there was a decline in the catch of Whiting and increases in the catch of Plaice and recruitment of Herring in the region (Weijerman et al. 2005).

How Ceratium species might impact higher trophic levels lies in their role within the phytoplankton community. It is acknowledged that species of Ceratium may exert a seasonal competitive advantage over other microphytoplankton, as they are able to tolerate a wide range of environmental conditions (Baek et al. 2007). Some studies suggest that a mixotrophic feeding strategy contributes to a competitive advantage (Mikaelyan and Zavyalova 1999; Smalley et al. 1999; Turin-Ley et al. 2009), allowing Ceratium species to overcome nutrient depleted waters above the thermocline and light depleted waters below the thermocline. Others highlight Ceratium as a poor food option for most species of grazing zooplankton due to their large size (Graneli et al. 1989) and characteristic shapes (Hargrave and Geen 1970). Smetacek (1981) drew links between increased abundances of Ceratium species and declines in the mesozooplankton community within the Baltic Sea. Here, the observations of Nielsen (1991) are of significance, who observed that only the largest copepod species and cladocerans are able to graze Ceratium, resulting in reduced energy transfer through to higher trophic levels. Therefore, species of Ceratium that become newly established in cool-water ecosystems have the potential to affect fisheries via reduced nutritional transfer. The establishment of warm-water Ceratium species in southern Tasmania may result in change to energy transfer through the ecosystem and a potential reorganisation of the phytoplankton community, which may have important consequences for commercial fisheries (Hays et al. 2005). However, due to the short timeline of our study coupled with limited available literature focussing on the ecological impacts of non-native Ceratium species, any predictions of ecological impact concerning introductions of Ceratium species into Southern Tasmanian ecosystems can only be speculative. It is the opinion of the authors that renewed emphasis must be placed on monitoring both phytoplankton and zooplankton communities in southern Tasmanian shelf waters to observe changes and explore trophic linkages. 
Despite a clear biological influence (transport of Ceratium), the EAC was not physically observed. Although it has strengthened in recent decades (Ridgway and Hill 2009), its physical influence is not known to extend westward into shelf waters past Storm Bay (Clementson et al. 1989), and no evidence of its physical signature was found by Cresswell (2000) at Bruny Island during its peak strength. The progress of the EAC south from Tasman Island appears tied to the shelf break (Harris et al. 1987), as later highlighted by Ridgway (2007), who presented SST satellite imagery in the period 1993-2003 depicting warm-water tongues of the EAC hugging the shelf break south of Tasman Island. However, SST imagery collated over the 2011-2012 summer period does imply movement of subtropical water over the continental shelf into coastal waters of southeast and south Tasmania. Indeed, Ridgway (2007) described the EAC as highly variable within the Tasmanian region. The SST imagery is somewhat supported by CONNIE2, which indicates the potential for flow of surface waters from the east into the study site. Therefore SST imagery and CONNIE2 not only support the role of the EAC in an onshelf transport of biology, but also highlight its potential for physically modifying southern shelf waters.

While no biological signature could be attributed to the LC, a strong physical signature was found for TS and nutrient properties in June and August, consistent with previous observations by made by Ridgway (2007) at the MINRS $\left(\sim 12{ }^{\circ} \mathrm{C}, 34.8-35.2 \mathrm{psu}\right.$, nitrate + nitrite $\sim 4 \mu \mathrm{M})$. In contrast to the erratic, eddy driven behaviour of the EAC in Tasmania, the LC provides a consistent transport of relatively warm and saline waters onto the southern Tasmanian shelf during winter (Ridgway 2007). SST satellite imagery collated during winter highlights the strong winter flow of the LC into southern shelf waters of Tasmania. The strength of the LC during winter is also reflected in the results of CONNIE2, where surface waters (5-25 m) flowed more strongly from the west. In our study the highest levels of nitrate + nitrite were found in surface waters of June and August (3.42 and $3.17 \mu \mathrm{M}$, respectively). Additionally, silicate concentrations remained uncharacteristically low $(<0.25 \mu \mathrm{M})$ in winter samples. This is in spite of previous studies at Storm Bay and Maria Island suggesting that the summer influx of the EAC created the lowest annual levels (Harris et al. 1987; Ridgway 2007; Ridgway and Hill 2009; Thompson et al. 2009). Low silicate, while often considered a characteristic of subtropical waters (Richoux and Froneman 2009), has not previously been associated with the LC. Instead, substantial declines in the LC's high silicate properties have been documented as the current tracks south along the WA coastline (Cresswell and Griffin 2004; Koslow et al. 2006). Despite the substantial knowledge gap concerning the current's nutrient properties between WA and Tasmania, we suggest that the LC may be severely depleted in silicate by the time it arrives in southern Tasmania.

Regardless of its strengthening influence in the region, the EAC did not appear to completely exclude the presence of subantarctic species, providing strong evidence that Southern Tasmania is a region of subtropical and subantarctic mixing. D. truncata, a subantarctic species thought to be particularly rare in temperate settings (G. Hallegraeff pers. comm.), was found in December surface samples coinciding with the warm-water Ceratium spp. This suggests that southern shelf waters are subject to the influx of subantarctic waters during summer. To our knowledge, few studies have explored the subantarctic influence in Tasmanian waters. Both Taw and Ritz (1979) and Clementson et al. (1989) presented evidence that both subtropical and subantarctic oceanic waters were present in coastal southeast Tasmania. Taw and Ritz (1979) found that the presence of these waters was having direct impacts on the zooplankton communities of Storm Bay. Harris et al. (1987) found a complex mixture of subtropical and subantarctic waters present in summer near Maria Island. The studies of Taw and Ritz (1979), Harris et al. (1987) and Clementson et al. (1989) are north of our study site, and so it follows that similar oceanographic dynamics, albeit with greater subantarctic influence, are affecting the biology of southern Tasmania. This is not surprising considering that the EAC is a highly dynamic, eddy-driven current (Ridgway 2007; Ridgway and Hill 2009), which appears to exert a pulsing influence on southern Tasmanian shelf waters. James et al. (2001) described a similar oceanographic dynamic in the Great Australian Bight, where southern waters were observed in shelf environments in summer when the LC is relaxed. The oceanography described by James et al. (2001) might also occur further along the LC's path. SST images present 3 pronounced subantarctic incursions into coastal regions of southern Tasmania during summer. One event featured water temperatures of 
approximately $14{ }^{\circ} \mathrm{C}\left(\sim 4{ }^{\circ} \mathrm{C}\right.$ below average) along the majority of the eastern Tasmanian coast in early February. This demonstrates the potential for strong subantarctic incursions even during peak EAC flow. Results from CONNIE2 support this. From 2001 to 2007, regardless of the strength of the EAC, modelled currents brought water from the south and southwest onto the southern Tasmanian shelf. We suggest that the irregularity of the EAC's dominance in summer, coupled with a weakened LC, allows incursions of subantarctic water, and thus subantarctic species, into southern Tasmania.

In addition to biological and model based evidence, various physical and chemical signals were observed from spring to summer that suggested the presence of subantarctic water. Firstly, fluctuations in silicate concentrations suggest subantarctic influence. Following near-depleted concentrations in winter $(<0.13 \mu \mathrm{M})$, silicate increased to the highest concentrations recorded for surface waters in September ( $\sim 1.2 \mu \mathrm{M})$, coinciding with the spring bloom and the transition phase between the LC and EAC. A weakening in the LC from winter to spring, indicative of this transition, is reflected by CONNIE2 outputs and in SST images taken during spring. We suggest that the large increase in silicate concentrations observed in September is due to this transition allowing incursions of subantarctic water from the southwest. Following depletion in October $(>0.5 \mu \mathrm{M})$, silicate remained high $(>1 \mu \mathrm{M})$ throughout summer. This is in contrast to previous research located further north that suggests silicate concentrations are lowest in summer due to the presence of the EAC (Harris et al. 1987; Ridgway 2007; Ridgway and Hill 2009; Thompson et al. 2009). High silicate concentrations throughout the summer are indicative of water from the Southern Ocean, known to be rich in nutrients (Falkowski et al. 1998). Secondly, February demonstrated spikes in nutrients of bottom waters (nitrate + nitrite $=5.55 \mu \mathrm{M}$, phosphate $=0.5 \mu \mathrm{M}$ and silicate $=1.88 \mu \mathrm{M})$ and a clear reduction in salinity $\left(\sim 0.2 \mathrm{~g} \mathrm{~kg}^{-1}\right)$ not observed in other months. Cresswell (2000) identified a similar freshening of waters south of Bruny Island in March and attributed it to cool and fresh waters from the southwest. This flow is likely the same responsible for the simultaneous enrichment of bottom waters and freshening observed.

Thirdly, chlorophyll $a$ data indicates subantarctic influence in the region. Chlorophyll $a$, while highest in subsurface waters $(0.5 \mathrm{~m})$ in September, consistently exhibited greater values at $10 \mathrm{~m}$ during summer months. This is uncharacteristic of temperate marine environments, which are considered more productive during spring and autumnal bloom events (Sverdrup 1953). A recent study focussing on the difference between marine subantarctic and subtropical seasonal production regimes presents a possible explanation. Nodder et al. (2005) found that Southwest Pacific subantarctic waters south of the subtropical convergence at $46^{\circ} 40^{\prime} \mathrm{S}$ supported sustained production during summer exceeding that produced during spring and autumn bloom events. This contrasted with production measured from a site north of the subtropical convergence at $41^{\circ} \mathrm{S}$, where chlorophyll $a$ values were consistent with a classical temperate cycle of primary production, in which spring and autumn bloom events represented peak production. Chlorophyll $a$ concentrations from our sites $\left(\sim 43.6^{\circ} \mathrm{S}\right)$ suggest that primary production is high both during the spring bloom event and throughout summer, with summer values equalling or exceeding those recorded during the spring bloom. This places southern Tasmania within the boundary of the subtropical convergence, where influence from both subantarctic and subtropical environments creates a hybrid production regime. Pearce (1981), using expendable bathythermographs (XBTs), positioned the subtropical convergence at approximately $44^{\circ} \mathrm{S}$ to the east of Tasmania. Stanton and Ridgway (1988) agreed with this placement. Ridgway (2007), however, suggests that the subtropical convergence now occurs south of Tasmania, rather than to the east, placing responsibility on the strengthening EAC. Our chlorophyll $a$ values suggest that southern Tasmania lies almost directly within the subtropical convergence. We suggest that this regime of primary production stems from a unique potential for simultaneous subantarctic and subtropical influence due to southern Tasmania's proximity to the subtropical convergence.

\section{Conclusions}

Here we provide new evidence that the poleward extension of the EAC is having biological consequences. A number of warm-water Ceratium species were identified in southern Tasmanian shelf waters with the onset of stratification and persisted into summer. The 
observation of these species represents expansions of their previously recorded ranges. In the face of climate change, southern Tasmanian shelf waters are currently experiencing noteworthy changes in the microphytoplankton community, not unlike shifts documented in the Northern Hemisphere. Improved understanding of the situation is important to ensure adequate fisheries management of potential impacts.

The physical absence of the EAC in summer and the strong presence of the LC in winter in shelf waters of southern Tasmania reveal an interesting seasonal oceanographic regime. Shelf waters in winter are dominated by LC water, while a weakened LC and an erratic EAC create a complex mixture of subtropical and subantarctic waters in summer. Put simply, southern shelf waters in summer experience periodic modifications towards subtropical or subantarctic properties depending on the temporal strength of the EAC, among other meteorological factors.

The influx of subantarctic waters into southern Tasmania has a direct effect on the seasonal dynamics of primary production. Due to proximity to the subtropical convergence both temperate and subantarctic primary production cycles are evident. The region experiences an annual spring bloom event and extended summer production, typical of temperate and subantarctic marine environments, respectively. The prevalence of this hybrid production regime requires additional exploration in other temperate settings in proximity to the subtropical convergence.

Acknowledgments Dr. David Griffin and the Ocean Current resource at the Integrated Marine Observing System were of great importance to our study. Prof. Gustaaf Hallegraeff was instrumental in confirming phytoplankton identifications. We thank Dr. Zanna Chase for sharing her knowledge of the Gibbs Sea Water Oceanographic package and Rob Johnson for coding in MatLab. Andrew Pender and Jason Beard were essential to data collection throughout the study period and their efforts in often less than optimal conditions must be noted. Finally, very special thanks must be extended to Dr. George Cresswell for helping shed light on the physical data.

\section{References}

ABARE (2010) Australian fisheries statistics 2009. Australian Bureau of Agricultural and Resource Economics, Canberra

Baek SH, Shimode S, Kikuchi T (2007) Reproductive ecology of the dominant dinoflagellate, Ceratium fusus, in coastal area of Sagami Bay, Japan. J Oceanogr 63(1):35-45

Barnard R, Batten SD, Beaugrand G, et al. (2004) Continuous plankton records: plankton atlas of the North Atlantic
Ocean (1958-1999). II. Biogeographical charts. Mar Ecol Prog Ser (Suppl.):11-75

Beaugrand G (2004) The North Sea regime shift: evidence, causes, mechanisms and consequences. Prog Oceanogr 60:245-262

Beaugrand G, Brander KM, Lindley JA, Souissi S, Reid PC (2003) Plankton effect on cod recruitment in the North Sea. Nature 42:661-664

Brander K (2010) Impacts of climate change on fisheries. J Mar Syst 79:389-402

Clementson LA, Harris GP, Griffiths FB, Rimmer DW (1989) Seasonal and inter-annual variability in chemical and biology parameters in Storm Bay, Tasmania. I. physics, chemistry and the biomass of components of the food chain. Aust J Mar Freshw Res 40:25-38

Condie SA (2005) Web site on marine connectivity around Australia. EOS Trans Am Geophys Union 86(26):246

Condie SA, Hepburn M, Mansbridge J. (2012) Modelling and visualisation of connectivity of the Great Barrier Reef. In: Proceedings of the 12th international coral reef symposium, Cairns, Australia, 9-13 July 2012

CONNIE (2012) CSIRO Connectivity interface. Available at: http://www.csiro.au/connie2/

Cresswell GR (2000) Currents of the continental shelf and upper slope of Tasmania. Proc R Soc Tasmania 133:23-30

Cresswell GR, Griffin DA (2004) The Leeuwin Current, eddies and subantarctic waters off south-western Australia. Mar Freshw Res 55:267-276

Dickson RR, Colebrook JM, Svendsen E (1992) Recent changes in the summer plankton of the North Sea. ICES Mar Sci Symp 195:232-242

Dodge JD, Marshall HG (1994) Biogeographic analysis of the armoured planktonic dinoflagellate Ceratium in the North Atlantic and adjacent seas. J Phycol 30:905-922

Doney SC, Ruckelshaus M, Duffy JE, Barry JP, Chan F, English CA, Glaindo HM, Grebmeier JM, Hollowed AB, Knowlton N, Polovina J, Rabalais NN, Sydneyman WJ, Talley LD (2012) Climate change impacts on marine ecosystems. Annu Rev Mar Sci 4:11-37

Edwards M, Richardson AJ (2004) Impact of climate change on marine pelagic phenology and trophic mismatch. Nature 430:881-884

Edwards M, Beaugrand G, Reid PC, Rowden AA, Jones MB (2002) Ocean climate anomalies and the ecology of the North Sea. Mar Ecol Prog Ser 239:1-10

Edwards M, Johns DG, Licandro P, John AWG, Stevens DP (2006) Ecological status report: results from the CPR survey 2004/2005. SAHFOS technical report, 3:1-8. ISSN 1744-0750

Falkowski PG, Barber RT, Smetacek V (1998) Biogeochemical controls and feedbacks on ocean primary production. Science 281(5374):200-206

Feistel R (2008) A Gibbs function for seawater thermodynamics for -6 to $80^{\circ} \mathrm{C}$ and salinity up to $120 \mathrm{~g} \mathrm{~kg}^{-1}$. Deep-Sea Research I 55:1639-1671

Graneli E, Carlsson P, Olsson O, Sundstrom B, Graneli W, Lindahl O (1989) From anoxia to fish poisoning: the last ten years of phytoplankton blooms in Swedish marine waters. In: Cosper EM et al (eds) Novel phytoplankton blooms: causes and impacts of recurrent brown tides and other unusual blooms. Springer, New York, pp 407-428 
Grasshoff K, Ehrhardt K, Kremling K (1983) Methods of seawater analysis. Verlag Chemie, Weinheim

Hallegraeff GM, Bolch CJS, Hill DRA, Jameson I, LeRoi J-M, McMinn A, Murray S, de Salas MF, Saunders K (2010) Algae of Australia: phytoplankton of temperate coastal waters. CSIRO Publishing, Australia

Hargrave BT, Geen GH (1970) Effects of grazing on two natural phytoplankton populations. J Fish Res Bd Can 27:13951403

Harris G, Nilsson C, Clementson L, Thomas D (1987) The water masses of the east coast of Tasmania: seasonal and interannual variability and the influence on phytoplankton biomass and productivity. Aust J Mar Freshw Res 38: $569-590$

Harris GP, Griffiths FB, Clementson LA, Lyne V, Van der Doe H (1991) Seasonal and interannual variability in physical processes, nutrient cycling and the structure of the food chain in Tasmanian shelf waters. J Plank Res 13:109-131

Hays GC, Richardson AJ, Robinson C (2005) Climate change and marine plankton. Trends Ecol Evol 20:337-344

Hill KL, Rintoul SR, Coleman R, Ridgway KR (2008) Wind forced low frequency variability of the East Australian Current. Geophys Res Lett 35:L08602. doi:10.1029/2007 GL032912

Hötzel G, Croome R (1998) A phytoplankton methods manual for Australian Rivers. Occasional paper 18/98, Land and Water Resources Research and Development Corporation, Canberra

Huisman JM (1989) The genus Ceratium (Dinophyceae) in Bass Strait and adjoining waters, Southern Australia. Aust Syst Bot 2:425-454

Integrated Marine Observing System (IMOS) (2012) Integrated marine observing system. Available at: http://imos.aodn. org.au/webportal/. Accessed 27 May 2012

James NP, Bone Y, Collins LB, Kyser TK (2001) Surficial Sediment of the Great Australian Bight: facies dynamics and oceanography on a vast cool-waters carbonate shelf. J Sediment Res 71(4):549-567

Johns DG, Edwards M, Richardson A, Spicer JI (2003) Increased blooms of a dinoflagellate in the NW Atlantic. Mar Ecol Prog Ser 265:283-287

Johnson CR, Banks SC, Barrett NS, et al (2011) Climate change cascades: shifts in oceanography, species' ranges and subtidal marine community dynamics in eastern Tasmania. J Exp Mar Biol Ecol. doi:10.1016/j.jembe.2011.02.032

Koslow JA, Greenwood J, Lourey M, Rosebrock U, Wild-Allen K, Margvelashvili N (2006) Coastal and shelf biogeochemistry and modelling. In: Keesing JK, Heine JN, Babcock RC, Craig PD, Koslow JA (eds) Strategic research fund for the marine environment final report, vol 2: the SRFME core projects. Strategic Research Fund for the Marine Environment, CSIRO, Australia, pp 123-185

Ling SD, Johnson CR, Ridgway K, Hobday AJ, Haddon M (2009) Climate-driven range extension of a sea urchin: inferring future trends by analysis of recent population dynamics. Glob Change Biol 15:719-731

McLeod DJ, Hallegraeff GM, Hosie GW, Richardson AJ (2012) Climate-driven range expansion of the red-tide dinoflagellates Noctiluca scintillans into the Southern Ocean. J Plankton Res 34:332-337
Mikaelyan AS, Zavyalova TA (1999) Vertical distribution of heterotrophic phytoplankton in the Black Sea during the summer period. Oceanol Russian Acad Sci 39:893-902

Nielsen TG (1991) Contribution of zooplankton grazing to the decline of a Ceratium bloom. Limnol Oceanogr 36(6): 1091-1106

Nodder SD, Boyd PW, Chiswell SM, Pinkerton MH, BradfordGrieve JM, Greig MN (2005) Temporal coupling between surface and deep-ocean biogeochemical processes in contrasting subtropical and subantarctic water masses, Southwest Pacific Ocean. J Geophys Res Oceans 110: C12017. doi:1029/2004JC002833

Parsons TR, Maita Y, Lalli CM (1984) A manual of chemical and biological methods for seawater analysis. Pergamon Press, Oxford

Pearce A (1981) Temperature-salinity relationships in the Tasman Sea. Division of Fisheries and Oceanography report 135, CSIRO

Pecl G, Frusher S, Gardner C, Haward M, Hobday A, Jennings S, Nursey-Bray M, Punt A, Revill H, van Putten I (2009) The east coast Tasmanian rock lobster fishery-vulnerability to climate change impacts and adaptation response options. Report to the Department of Climate Change, Canberra

Punt AE, Kennedy RB (1997) Population modelling of Tasmania rock lobster, Jasus edwardsii, resources. Mar Freshw Res 48:967-980

Reid PC, MdF Borges, Svendsen E (2001) A regime shift in the North Sea circa 1988 linked to changes in the North Sea horse mackerel fishery. Fish Res 50:163-171

Richardson AJ (2008) In hot water: zooplankton and climate change. ICES J Mar Sci 65(3):279-295

Richoux NB, Froneman PW (2009) Plankton trophodynamics at the subtropical convergence, Southern Ocean. J Plankton Res 31:1059-1073

Ridgway KR (2007) Seasonal circulation around Tasmania: an interface between eastern and western boundary dynamics. J Geophys Res 112:C10016. doi:10.1029/2006JC003898

Ridgway K, Hill K (2009) The East Australian Current. In: Poloczanska ES, Hobday AJ, Richardson AJ (ed) A marine climate change impacts and adaptation report card for Australia 2009, NCCARF Publication 05/09, ISBN 978-1921609-03-9

Scavia D, Field JC, Boesch DF, Buddemeier RW et al (2002) Climate change impacts on U.S. coastal and marine ecosystems. Estuaries 25:149-164

Smalley GW, Coats DW, Adam EJ (1999) A new method using microspheres to determine grazing on ciliates by the mixotrophic dinoflagellate Ceratium furca. Aquat Microb Ecol 17:167-179

Smetacek V (1981) The annual cycle of protozooplankton in the Kiel Bight. Mar Biol 63:1-11

Stanton BR, Ridgway NM (1988) An oceanographic survey of the subtropical convergence zone in the Tasman Sea. N Z J Mar Freshw Res 22:583-593

Sverdrup HU (1953) On conditions for the vernal blooming of phytoplankton. J Cons Explor Mer 18:287-295

Tarbath D, Gardner C (2011) Abalone fishery assessment: 2010. Institute of Marine and Antarctic Studies, University of Tasmania, 2011

Taw N, Ritz DA (1979) Influence of subantarctic and subtropical oceanic water on the zooplankton and hydrology of 
waters adjacent to the Derwent River Estuary, Southeastern Tasmania. Aust J Freshw Res 30:179-202

Thompson PA, Bonham PI, Swadling KM (2008) Phytoplankton blooms in the Huon Estuary, Tasmania: top-down or bottom-up control? J Plankton Res 30(7):735-753

Thompson PA, Baird ME, Ingleton T, Doblin MA (2009) Longterm changes in temperate Australian coastal waters: implications for phytoplankton. Mar Ecol Prog Ser 394:1-19
Turin-Ley A, Ibanez F, Labat J-P, Zingone A, Lemee R (2009) Phytoplankton biodiversity and NW Mediterranean Sea warming: changes in the dinoflagellate genus Ceratium in the 20th century. Mar Ecol Prog Ser 375:85-99

Weijerman M, Lindeboom H, Zuur AF (2005) Regime shifts in marine ecosystems of the North and Wadden Sea. Mar Ecol Prog Ser 298:21-39 